
\title{
25 Research Square \\ Odonata Timetree; Exponentially Increased Base Substitution Rate Toward The Recent and Within the Carboniferous
}

Soichi Osozawa ( $\sim$ kawaoso@icloud.com )

Tohoku University

John Wakabayashi

Tohoku University

\section{Research Article}

Keywords: BEAST v1.X, fossil and geological event calibration, 1.55 Ma, $400 \mathrm{Ma}$, exponentially increased base substitution rate, Quaternary, Carboniferous, glacier period

Posted Date: December 10th, 2020

DOI: https://doi.org/10.21203/rs.3.rs-116942/v1

License: (c) (i) This work is licensed under a Creative Commons Attribution 4.0 International License.

Read Full License 


\section{Abstract}

Using BEAST v1.X, we constructed a credible timetree of 115 specimens of Odonata and five species of Ephemeroptera (Paleoptera; Pterygota) and two species of Archaeognatha and three species of Zygentoma (Apterygota). 88 specimens we ourselves analyzed were collected from the Ryukyu islands, Taiwan, Japan, and China, and the resting sequence data were mostly from whole mitochondrial data found in GenBank / DDJB. The combined gene (not concatenated gene) analysis of the mitochondrial COI (795 bp), COII (548 bp), and 16S rRNA (517 bp), and the nuclear 28S rRNA (825 bp) were performed. Using the calibration function of BEAST v1.X, the timetree was constructed by applying a $1.55 \mathrm{Ma}$ geological event (isolation of the Ryukyu islands from China), in addition to chronologically robust fossil dates ranging from $400 \mathrm{Ma}$ for Archaeognatha, $300 \mathrm{Ma}$ for Ephemeroptera, and $200 \mathrm{Ma}$ for Odonata and to $1.76 \mathrm{Ma}$ for Calopterygidae, for a total of 13 calibration points (event: 6, fossil: 12; Quaternary 7, pre Quaternary 11). The resultant timetree showed that molecular clock was not uniformly progressed, and the base substitution rate has exponentially increased from ca. $20 \mathrm{Ma}$ to the Recent by over an order of magnitude. Our new and attractive finding indicates that the Quaternary severe climatic change including a start of glacial and interglacial cycle might have resulted in the extensive radiation and speciation of Odonata, and consequently increased the biodiversity. C4 pores generated in the Miocene effectively decreased atmospheric $\mathrm{CO} 2$, and triggered the Quaternary glaciation. Another peak of base substitution rate was found in the Carboniferous time around $320 \mathrm{Ma}$, and this may be analogous to the late Paleozoic icehouse. This glaciation has been triggered by the development of terrestrial plants to form thick coal layers, because this process also reduced the atmospheric $\mathrm{CO} 2$.

\section{Introduction}

A reliable timetree (dated phylogeny) for the entirety of Odonata (dragonfly and damselfly) have not yet been reported to date, except for the very recent report in bioRxiv (Kohli et al., 2020). We have presented the timetree of the east Asian Coeliccia damselfly (details of the vicariance in Osozawa et al., 2017c) calibrated solely by the Quaternary date of geological event ( $1.55 \pm 0.15 \mathrm{Ma}$; isolation of the RyukyuJapan-Taiwan islands from China; triggered the vicariant speciation onto the most recent common ancestor of the present each island and Chinese endemic species; no geological evidence of land bridge for dispersal; Osozawa et al. 2012). A problem with that analysis was that calculated basal node age of several million years was younger than what would be considered reasonable. This chronological problem also existed in analyses of other East Asian Odonata timetrees (Anotogaster dragonfly, Osozawa et al. 2013; Chlorogomphus dragonfly, Osozawa and Wakabayashi, 2015), and other east Asian insects (Papilio butterflies, Osozawa et al., 2013; Mycalesis butterfly, Osozawa et al., 2015a; Pyrocoelia firefly, Osozawa et al., 2015b; Cicindela tiger beetle, Osozawa et et al., 2016; Ypthima butterfly, Osozawa et al., 2017a; Platypleura cicada, Osozawa et al., 2017b; Carabid ground beetle, Osozawa K. et al., 2016). Note that extensive vicariance by the isolation of islands from the Chinese continent was described and established in these papers. 
Insecta consists of Apterygota and Pterygota, and we included Apterygota of Archaeognatha (jumping bristletail) and Zygentoma (silverfish) as outgroup applying sequence data from GenBank / DDBJ. Pterygota consists of Palaeoptera, ancestral group of insects that lacks/lacked the ability to fold the wings back over the abdomen, and Neoptera in contrast to Palaeoptera (Ishiwata et al. 2011). Odonata as a main target and Ephemeroptera (mayfly) belong to Palaeoptera, and we included Ephemeroptera in our analyses applying sequence data in GenBank / DDBJ. Odonata consists of Anisoptera (dragonfly) and Zygoptera (damselfly), and includes Anisozygoptera with an intermediate form between them.

Epiophlebia superstes (Epiophlebiidae) is a representative species of Anisozygoptera in the Japanese islands, and historically considered to be extant, relict, and primitive (Asahina, 1954; Ishida et al., 1988; Hasegawa and Kasuya, 2006; Ozano et al., 2012; Busse et al., 2012, 2015; Wang et al., 2014). We ourselves collected and analyzed East Asian Odonata covering every family as possible (Figs. 1 and 2), and attempted to construct a credible Odonata timetree including E. superstes with the initial goal of resolving the apparent chronologic discordance problem noted above. The expectation was that $E$. superstes lineage should be very old up to $200 \mathrm{Ma}$, rather than several million years. Apterygota and Ephemeroptera lineage should be very old up to the Paleozoic.

Divergence time estimation is possible employing conventional MCMCTree (Yang, 2007). As for the fossil calibration, minimum and maximum age constraints or bounds for a specific node are defined (Benton and Donoghue, 2007). The minimum age is the oldest fossil age known, and younger than the branch node. The maximum age is such as a stem age defined by additional fossil age older than that branch node. The latter is usually difficult to determine and unclear, and overestimated in many cases. The overestimate affects on large error bar at node and shifts the divergence estimate older date found in Kohli et al. (2020). Note that two age data set specifying a node is needed for MCMCTree analysis. Another complex treatment is required; building concatenated gene and re-partitioning using PartitionFinder. We are unfamiliar with the command line user interface.

BEAST v1.X released on 10th June, 2018 (Bayesian Evolutionary Analysis Sampling Trees; Suchard et al., 2018) has a function of calibration in the associated software of BEAUti (Bayesian Evolutionary Analysis Utility). The calibration protocol of BEAUti is to input a time of the most recent common ancestor (tMRCA = minimum age) of the ingroup species (e.g., calibration point $\mathrm{H}$ for Libellulidae species; Fig. 1), either by fossil calibration or by the geological event calibration noted above. Using BEAST v1.X, without fixing maximum age constraint, we can simply build a reliably-dated phyologeny of Apterygota and Palaeoptera including the target Odonata (Fig. 1). The combined gene analysis of the mitochondrial COI (795 bp), COII (548 bp), and 16S rRNA (517 bp), and the nuclear 28S rRNA ( $825 \mathrm{bp}$ ) can be performed by simply setting partitions of these genes in BEAUti, and concatenation and re-partitioning using PartitionFinder is not required. Note that our employed mitochondrial genes have high resolution compared to the nuclear genes, applicable for very old age without saturation of mutation (Osozawa et al., 2012, 2017c), but unrelated to the above chronological problem.

The topology of the resulting timetree was controlled by these calibration points and date sets in BEAUti, and prior age (input in BEAUti) and posterior age (output in FigTree) shown in Fig. 2 must be coincident. 
This means that the BEAST v1.X calibration is an "active" one. If the timetree has unreasonable shape and very distinct input and output age, we reset the calibration and repeatedly run BEAST until to get reasonable one.

In our previous analyses such as for Coeliccia damselfly in Osozawa et al. (2017c), we calibrated by geological event of $1.55 \mathrm{Ma}$ and applied strict clock model in BEAST v1.8.2 analyses with the same calibration function to v1.X, and represented the base substitution rates of rapid mitochondrial and slower nuclear genes respectively. The rate was comparable to the previously reported rates such as by Brower (1994), although the rate was represented as relatively high (solution of the above problem is addressed below). Our present BEAST v1.X analyses applied relaxed clock model alternative to the strict clock model in Osozawa et al. (2017c), and the rate median at each node is not constant but valuable.

We made rate vs age diagram (Figs. 1 and 2 inset) to verify the variability, and as a main result we indicate an order of magnitude increase of base substitution rate in Odonata evolutional history found in the Quaternary and also in the Carboniferous. We propose here that the consequent increased biodiversity of Odonata was driven by severe environmental change that began in the Quaternary, and by global glaciation during the Carboniferous. We also discussed the ultimate factor of these glacier events, which was connected to the plant evolution.

\section{Results}

\section{Timetree (Figs. 1 and 2)}

Insecta basal node was estimated at $413 \mathrm{Ma}$, Archaeognatha was represented as the oldest lineage in insecta, and Zygentoma is second. Ephemeroptera is a sister of Odonata differentiated at $347.56 \mathrm{Ma}$, and this Palaeoptera is a sister of Apterygota (Archaeognatha + Zygentoma).

Anisoptera is a sister of Zygoptera, and each forms distinct major clade. Although Epiophlebia superstes is included in the Anisoptera clade, it can be considered to represent a distinct clade as an intermediate Anisozygoptera, concordant to Hasegawa and Kasuya (2006) and Misof et al. (2014). E. superstes persists as an old lineage with a long terminal branch, and the species age is estimated at 180.17 m.y. expressing the deep evolutionary history.

As for another relict species, Petaluridae (Ware et al., 2015), age of the MRCA was estimated at 141.33 Ma as calibrated by point $F$ of $142.4 \pm 2.6 \mathrm{Ma}$, and differentiated from Gomphidae at $149.7 \mathrm{Ma}$ (branching order 2 in Figs. 1 and 2). However, the differentiation into each species was relatively young around $10 \mathrm{Ma}$.

Aeshnidae occupies a relatively old position as old as $149.01 \mathrm{Ma}$ (branching order 1), and a sister of Cordulegastridae + Chlorogomphoidea differentiated at 146.11 Ma (branching order 3). Excepting this sister relationship, the topology is concordant to that of Kohli et al. (2020). 
Date of MRCA of monophyletic Gomphidae is estimated at $130.57 \mathrm{Ma}$, and the topology is totally concordant to the North American genera reported by Ware et al. (2017; not a dated tree). Epigomphinae is an old lineage in Gomphidae, and a sister of the other Gomphidae species.

Libellulidae is a sister of Corduliidae, and differentiated at $138.38 \mathrm{Ma}$ (branching order 4). The MRCA is estimated at relatively young age of $51.25 \mathrm{Ma}$

For analyzed Zygoptera, Sinostica ogatai (Platystictidae) and Sympecma paedisca (Lestidae) constituted an old lineage and was a sister of the resting Zygoptera. Each Zygoptera family constituted a distinct clade, excepting for Mesopodagrion tibetanum (see discussion, timetree).

Multi-furcation into the Rykyu-Taiwan-Japan island species including Chinese species, reflecting vicariance started at $1.55 \mathrm{Ma}$, is observed for four ingroup species for Anisoptera (Q1 to Q4), and two ingroup species for Zygoptera (Q5 and Q6), as calibrated by this 1.55 Ma date. However, minor discordance between input date and output date was observed for Asiagomphus, Anotogaster, Chlorogomphus, and Coeliccia.

\section{Base Substitution Rates}

Base substitution rate vs age diagram (Figs. 1 and 2 inset) shows that the rate is not constant as applied relaxed clock model, but tends to have exponentially increased since ca. $20 \mathrm{Ma}$, and the equation of the trendline is shown on the inset. The rates less than 0.01 substitutions/site/myr (s/s/myr) between ca. $200 \mathrm{Ma}$ and $20 \mathrm{Ma}$ were exponentially increased up to $0.2183 \mathrm{~s} / \mathrm{s} / \mathrm{myr}$ of vicariantly speciated Rhipidolestes in the Recent time.

Because our timetree covered after $400 \mathrm{Ma}$ of post Silurian by calibrated by up to $400 \mathrm{Ma}$ by point $\mathrm{A}$, the base substitution rate vs age diagram (Figs. 1 and 2 inset) recorded such ancient variation of rates. We found another peak of rate around $320 \mathrm{Ma}$ of late Carboniferous. The peak rate was 0.063 at the basal node of Palaeoptera (Ephemeroptera + Odonata).

\section{Discussion}

\section{Timetree (Fig. 3)}

Insecta basal node was estimated at $413 \mathrm{Ma}$, younger than estimate of $479 \mathrm{Ma}$ by Misof et al. (2014), and that of Palaeoptera (Ephemeroptera + Odonata) of Pterygota was estimated at 317.29 Ma, also younger than $406 \mathrm{Ma}$ for whole Pterygota and $362 \mathrm{Ma}$ for Palaeoptera by Misof et al. (2014). Misof et al. (2014) employed BEAST v.1.8 with the same calibration function to BEAST v1.X, and the discordance might be simply arisen from our robust calibrations. As we note in methodology bellow, the Kyrgyzstan damselfly fossil date applied by Misof et al. (2014) was not useful.

Note that ancient divergence times were successfully estimated by our mitochondrial gene application, with no sign of saturation of mutations, and application of nuclear gene was not affected on the 
topology and divergence time. Actually the base substitution rate of combined gene (Figs. 1 and 2 inset) is comparable to that of solely mitochondrial gene (Osozawa et al., 2017c).

The Odonata topology is comparable to Kohli et al. (2020). Epiophlebiidae is the oldest lineage. In Anisoptera, as numbered in Figs. 1 and 2, branching order is Aeshnidae (1), Petaluridae (2) and its sister of Gomphidae (2), Cordulegastridae (3) and its sister of Chlorogomphoidea (3), Corduliidae (4) and its sister of Libellulidae (4), same as the order of Kohli et al. (2020). Aeshnidae is a sister of Cordulegastridae + Chlorogomphoidea, which differs from Kohli et al. (2020). In Zygoptera, Lestidae and also Platystictidae is an old lineage relative to the resting. Discordance of divergence times might reflect overestimate of maximum bounds in Kohli et al. (2020).

In introduction, we noted a problem that the basal node age was estimated much younger than expected age when calibrated solely by the Quaternary geological event at $1.55 \mathrm{Ma}$. This problem was solved by contemporaneously applying old ages calibrated by fossil calibration points from A ( $400.45 \mathrm{Ma}$; Devonian) to I (1.76 Ma; Quaternary) in addition to geological event at 1.55 Ma (Quaternary) from Q1 to Q6, and the consequent dated tree (Figs. 1 and 2 ) is reliable.

Epiophlebia superstes can be considered to be included in the Anisoptera major clade, and is a sister of the other Anisoptera, common to Kohli et al. (2020). The stem age was estimated to be $189.5 \mathrm{Ma}$, but younger than $200.3 \pm 1.0 \mathrm{Ma}$ of calibration point $\mathrm{C}$. In the Anisoptera clade, E. superstes persists as an independent lineage, so classification to Anisozygoptera was possible, and the species age is as old as 180.17 m.y. Accordingly, E. superstes can be considered a living fossil. Genus Epiophlebia is known from isolated areas of the Japan islands, China (the same species to China was reported also from North Korea; Gunther et al., 2013), and the Himalaya, but the vicariance was indicated to be very mild, suggesting that the isolation in these areas occurred recently and is unrelated to its very old lineage (Busse et al., 2012).

Petaluridae including Tanypteryx pryeri and Petalura gigantea was dated at 149.7 Ma (early Cretaceous). Ware et al. (2014) proposed that Petaluridae is an old species dating back to the Jurassic, reflecting the breakup of the supercontinent Pangaea. As we note in methodology, the Pangaea breakup and initiation of the Atlantic Ocean was recorded in the Santana Formation, and may at 125 - $100 \mathrm{Ma}$ (Martill, 2007), which is younger than the stem node age of Petaluridae. However, Petaluridae can be considered to be primitive and extant species (Ware et al., 2014).

Family level differentiations for Anisoptera were occurred during early Cretaceous time around $130 \mathrm{Ma}$, and those for Zygoptera were occurred during Paleogene to early Neogene between 72.64 to $22.19 \mathrm{Ma}$. So family age of Zygoptera is younger than that of Anisoptera. Subspecies level differentiations of Gomphidae were during Paleogene. Species level differentiation was after Paleogene, but mostly Neogene, and endemic species calibrated by $1.55 \mathrm{Ma}$ as points Q1 to Q6 were differentiated during the Quaternary. 
Yu and Bu (2011) cladistically analyzed damselflies, and showed that Mesopodagrion and Rhipidolestes possess in distinct clade, and Megapodagrionidae was divided into two distinct families. Two distinct clades of Megapodagrionidae in Figs. 1 and 2 reflect this subdivision.

\section{Vicariance increased biodiversity}

Q1: Stylogomphus, Q2: Asiagomphus, Q3: Anotogaster, Q4: Chlorogomphus (Osozawa and Wakabayashi, 2015), Q5: Rhipidolestes, Q6: Coeliccia (Osozawa et al., 2017c) were calibrated by the $1.55 \pm 0.15 \mathrm{Ma}$ geologic event, and each of the multi-furcation or polytomy indicates the generation of multi- endemic species (Fig. 2). Isolation of islands by the opening of the Okinawa trough is a physical process, but such process clearly triggered increasing biodiversity. These endemic species might have experienced a severe bottleneck by the isolation of habitat, but the bottleneck might have effect on species the low diversity and the low nucleotide substitution rate (Zhai et al., 2017), which is conflict to the present case.

Calibration point I: Calopteryx + Matrona was calibrated by fossil date of $1.76 \pm 0.22 \mathrm{Ma}$, and splitting between Calopteryx japonica (Japan) and Matrona basilaris (Amami-Okinawa; failed to amplify Taiwan specimen) appears to be a consequence (or a precursor) of 1.55 Ma vicariance (Fig. 2).

In general, back arc spreading to form continental islands may trigger vicariance that increases extent of biodiversity. There are many back arc basins in the western Pacific Ocean, and some are still active, including the Okinawa trough. The high diversity of terrestrial organisms observed on continental islands separated from continental landmasses by sea-floor spreading of this sort may be a consequence of the physical isolation of these islands by the rifting process and the consequent vicariance.

In contrast, the oceanic islands are also generated back arc spreading by building of volcanic edifices in the ocean, but these had no terrestrial life prior to their formation of islands because they emerged above sea level as a result of progressive volcanism. Such islands initially acquired their terrestrial species by dispersal from other land masses, and the species diversity associated with such islands may be expected to increase by vicariance after initial colonization by dispersal (cf., Osozawa, K. et al., 2016).

We showed that lotic damselflies tended to speciate vicariantly in contrast to the lentic damselfly (Osozawa et al., 2017c), and the similar report was by Letsch et al. (2016). However, as for Octogomphinae, lotic Davidius and lentic Trigomphus show no such tendency (Fig. 2). Libellulidae is mostly lentic, and vicariance may be negligible (= same sequence between island populations), and resulting in low species diversity, but we failed to amplify enough island specimens of Libellulidae to fully evaluate this premise. This is a case also for mostly lentic Coenagrionidae damselfly by lacking corresponding sequence data.

\section{Increase base substitution rate and biodiversity}

Base substitution rates estimated by calibration with $1.55 \mathrm{Ma}$ geologic event of Q1 to Q6 are relatively high ( $>0.01 \mathrm{~s} / \mathrm{s} /$ myr including $>0.1 \mathrm{~s} / \mathrm{s} / \mathrm{myr}$ ), and comparable to those that we estimated recently for other insects using the same calibration event (Osozawa et al., 2013, 2015ab, 2016, 2017a-c; Osozawa, K. 
et al., 2016; Osozawa and Wakabayashi, 2015). However, ages of older nodes were underestimated, and branch lengths were shortened, when using this Quaternary geologic calibration alone.

Base substitution rates estimated by old fossil dates of $A$ to I for calibration are $<0.01 \mathrm{~s} / \mathrm{s} /$ myr, and these resulted in older nodes and extension of branches. Both the fossil calibrations including the Quaternary of point I and the Quaternary geologic event calibrations of point Q1 to Q6 appear to be robust, so the discrepancy might be the result of changing base substitution rates that may have been relatively constant from $200 \mathrm{Ma}$ at slower rate, but exponentially increased since at ca. $20 \mathrm{Ma}$, especially during the Quaternary (Figs. 1 and 2 inset).

By applying both geologic and fossil calibrations and using a relaxed clock model in BEAUti, we obtained an accurate BI tree in calibration and topology (= accurate timetree; Figs. 1 and 2). But additional important result is that the molecular clock hypothesis (relatively constant rate over time; Ho 2008) is unacceptable for Odonata evolution, and the rate exponentially increased toward the Recent (Figs. 1 and 2 inset).

This phenomenon had been shown for taxa such as primates (Ho et al., 2005, 2011) and Aegean beetles (Papadopoulo et al., 2010), but generated little attention. BEAST v1.X may simultaneously apply multiple calibration points as done for constructing Figs. 1 and 2, but BEAST v.1.3 (Ho et al., 2005) and BEAST v.1.4 (Papadopoulo et al., 2010) needed to run repeatedly by applying a date at every calibration point, and a rate at every run was assumed to be constant at each node (= strict clock model). They found that a Quaternary date calibration produced a rapid rate. Note that we instantaneously calibrated by multi dates including older dates up to the Devonian as well as younger dates of the Quaternary, rather than solely calibrating by the Quaternary date, and the increasing rate is not solely an artifact of the Quaternary calibration. It should also be noted that combined gene analyses were not possible in these older versions of BEAST, and such the users needed to discuss the rate for every each gene such as COI vs $28 \mathrm{~S}$ rRNA. Therefore, although their trendlines and the equations are similar to ours, their timetrees are actually incorrect by not reflecting drastic changing of base substitution rates through the time, but by assuming a constant rate as if governed by the strict clock.

Increased base substitution rate may be expected to increase biodiversity, as is the case for the $1.55 \mathrm{Ma}$ vicariance-induced biodiversity mentioned above. Vicariance is partly explained as radiation for Rhipidolestes amamiensis as forming distinct clades (Fig. 2). An alternative is that greater apparent biodiversity in geologically recent time may be an artifact of the greater availability (preservation) and consequent greater number of studies of recent geological sections (Rohde and Muller, 2005). Molecular phylogenetic analyses combined with paleobiological study (Sahney et al., 2010; Neige, 2015; Buatois and Mángano, 2018) can test these alternatives.

A possible forcing factor of exponentially increasing evolution rate and probable biodiversity toward the Recent may be the start of glacial and interglacial cycle and the environment change in the Quaternary time since $2.58 \mathrm{Ma}$. The Quaternary glaciations may have been triggered by expansion of C4 land grasses and evolution of sea diatoms, because this process increased the carbon fixation that 
consequently decreased atmospheric CO2 concentration (Taira, 2007). The expansion of C4 grasses was a global phenomena also including North America and South America beginning in the late Miocene and persisting to the present day, concerning the present glacial-interglacial period with a time lag (Cerling et al., 1997).

We found another peak of base substitution rate in the Carboniferous time ( $300-350 \mathrm{Ma} ; 0.063 \mathrm{~s} / \mathrm{s} / \mathrm{myr}$ at the node between Ephemeroptera and Odonata; Figs. 1 and 2 inset), and this may be analogous to the late Paleozoic icehouse (= the Karoo ice age in South Africa; Montañez et al., 2013). Whereas glacial episodes in Earth history appear to be influenced by landmass configuration also in this period, feedback from biologic development may have also played a role in triggering the onset on this glaciation. The late Paleozoic glaciation had been triggered by the development of terrestrial plants to form thick coal layers in the Carboniferous time (Franks et al., 2014), because this process also increased carbon fixation that effectively reduced atmospheric CO2 (Taira, 2007).

\section{Conclusion}

Constant evolution rates that are the basis of the strict molecular clock model do not apply in the cases of Odonata and may not apply in a broader sense. The present biodiversity including Odonata may be a consequence of a geologically recent exponential increase in base substitution rate. This may reflect the onset of Quaternary glacial and inter glacial cycles associated with severe climatic change, triggered adaptive radiation of Odonata. Another peak was found in the Carboniferous time, also tied to the late Paleozoic icehouse.

\section{Materials}

\section{East Asia Odonata sampling}

Sequence data including whole mitochondrial data for several species of Archaeognatha, Archaeognatha, Ephemeroptera, and Odonata that we did not analyzed or failed to get sequence data were found in GenBank / DDBJ and included in our BEAST v1.X analysis (Fig. 2).

Location map is in Fig. 3, and representative collected specimens are shown on Fig. 4. DNA sequence data are newly registered in the DDBJ / GenBank, excluding previously uploaded data of Chlorogomphus by Osozawa and Wakabayashi (2015) and Coeliccia by Osozawa et al. (2017c). Species isolate, country, accession number, collection date, and collector data newly obtained in this paper are shown in Table 1. Species names are after Ozono et al. (2012).

Stylogomphus (Octogomphinae; Gomphidae; lotic) contains S. suzukii (Japan), S. chunliuae Chao, 1954 (China), S. shirozui (Yaeyama and Taiwan), S. ryukyuanusryukyuanus (southern Japan, Amami), and S. ryukyuanus asatoi (Okinawa). 
We collected lotic Davidius nanus, D. moiwanus, and Lanthus fujiacus (Octogomphinae; Gomphidae; Japan; Kiyoshi and Sota, 2006), and lentic Octogomphinae species of Trigomphus citimus tabei and T. interruptus (southwest Japan), and T. melampus (northeast Japan). We will compare the extent of vicariance of these species with contrasting habitat, as analyzed in Osozawa et al. (2017c).

Sieboldius albardae (Lindeniinae; Gomphidae; Japan and Korea; lotic) is characterized by small head relative to large body.

Asiagomphus (Gomphinae; Gomphidae; lotic) contains endemic A. melaenops (Japan), A. amamiensis amamiensis (Amami), A. amamiensis okinawanus (Okinawa), A. yayeyamensis (Yaeyama), and $A$. hainanensis (Taiwan and southern China, but China specimen was not obtained), expressig a typical vicariant speciation from a common ancestor. We also collected $A$. pryeri (Japan) and closely related $A$. coreanus (Korea) with sympatric lotic habitat to the above Asiagomphus species.

We collected Leptogomphus (Epigomphinae; Gomphidae) of L. yayeyamensis (Yaeyama) and L. sauteri (Taiwan), but did not find L. elegans (southern China). Leptogomphus is absent on Amami island and Okinawa.

Chlorogomphus (Chlorogomphoidea; lotic) contains C. brunneus brunneus (southern Japan and Amami), C. brunneus costalis (Okinawa), C. iriomotensis (Yaeyama), and C. risi (Taiwan). The Japanese population was probably relatively recently dispersed from Amami by typhoon (Osozawa and Wakabayashi, 2015). We failed to obtain 16S rRNA data from C. risi, and the species was not included in the Chlorogomphus ingroup in Fig. 2. We collected $C$. okinawensis (Okinawa) sympatric with $C$. brunneus costalis, but did not find $C$. suzukii (Taiwan) sympatric with $C$. risi. We collected Chlorogomphus sp. in China.

Anotogaster (Cordulegastridae; lotic) consists of A. sieboldii (Japan-Korea, Amami, and Okinawa), and $A$. klossi (Yaeyama, Taiwan, and China) (Kiyoshi, 2008; Osozawa et al., 2013), but our analyses were limited by partial mis-amplification.

Tanypteryx pryeri (Petaluridae; endemic in Japan) was considered to be morphologically and phylogenetically an extant, relict, primitive species with the other Petaluridae originated from the Pangean super continent, and the larvae live in fens and boggy seeps taking several years to mature (Ware et al. 2014). We analyzed other three Petaluridae species including $P$. gigantea, the world's largest dragonfly found in Australia, using corresponding sequence data in Ware et al. (2014), although their data were not complete.

We collected many Aeshnidae species, but we only obtained the COI- COll sequence data from Polycanthagyna melanictera (Okinawa; lentic), due to mis- or no amplification. P. melanictera is mostly known from Japan, as well as such as Tobi-shima off shore of Sakata, northern Honshu, and also Hachijo-jima of the Izu-Bonin oceanic islands, indicating its strong dispersal ability by flying. Anaxparthenope is a very common species in the coastal area near Sendai (northeast Honshu), persisting 
after the 2011 Tsunami, but only A. imperator and A. junius data were available in GenBank / DDJB. We also failed to obtain reliable sequence data of Oligoaeschna pryeri (Japan), considered to be a primitive species in Aeshnidae (Ozano et al., 2012).

Although we collected Corduliidae and some are endemic species in the Ryukyu islands, we failed to amplify the sequences. However, corresponding sequence data for three Corduliidae species were available in GenBank / DDJB.

Owing to mis-amplification of COI- COll regions, our analyses of Libellulidae were limited to sg38 Orthetrum japonicum (Fig. 2; Table 1). To facilitate calibration using the age of fossil Libellulidae, we also used GenBank / DDJB sequence data of whole mitochondrial. Libellulidae species are mostly lentic and commonly found on even small islands of Ryukyu, but an exception is lotic Sympetrum pedemontanum elatum (Japan; no COI- COll sequence data). However, we included S. eroticum (lentic) using GenBank / DDBJ data.

We collected Epiophlebia superstes (Anisoptera; lotic) from the Sendai hill (newly found habitat by the senior author) of northern Honshu. The larva spends 5 to 8 years in small streams, and leaves the water just before the emergence (Ozono et al., 2012).

We included lotic Calopterygidae of Atrocalopteryx atrata (Japan, Korea, China), Calopteryx japonica (Japan and Korea), and Matrona japonica (Amami and Okinawa). Fossil Calopteryx and Oligoaeschna pryeri (Aeshnidae) have been identified in Quaternary strata in Kyushu, Japan (Esaki and Asahina, 1957) enabling a Quaternary fossil calibration other than geological event calibration of $1.55 \mathrm{Ma}$. Other Matrona species collected in Taiwan and China were mis-amplified and no data in GenBank / DDBJ.

We collected Rhipidolestes (Megapodagrionidae; lotic; cascade) of $R$. hiraoi (Shikoku), R. yakusimensis (Kyushu and Yaku-shima), R. asatoi (Koshiki-jima), R. amamiensis (Amami), R. shozoi (northern Okinawa), R. okinawanus (southern Okinawa; allopatric to $R$. shozoi), and $R$. aculeatus (Yaeyama and Taiwan). The isolated cascade habitat may affect vicariance on this species. We also included in our analyses Agriomorpha fusca May, 1933 (Argiolestinae; China).

We had previously analyzed vicariantly speciated lotic Coeliccia (Platycnemididae) of C. ryukyuensis amamii (Amami), C. ryukyuensis ryukyuensis (Okinawa), C. flavicauda masakii (Yaeyama), C. flavicauda flavicaud (southern Taiwan; The Yilan basin and Lanyang valley is the barrier), and $C$. cyanomelas (northern Taiwan and China), with comparison to lentic Copera (Platycnemididae) of $C$. marginipes (Taiwan and China) and $C$. annulata (Japan), and lotic Platycnemis (Platycnemididae) of $P$. foliacea sasakii (Sendai, northern Honshu; northern limit) and P. phyllopoda (Korea) (Osozawa et al., 2017c).

We included two Zygoptera species of lotic Sinostica ogatai (Platystictidae; China; Osozawa et al. 2017c), and lentic Sympecma paedisca (Lestidae; Japan; GenBank / DDJB; primitive in Zygoptera; Ozono et al., 2012), other than several Euphaeidae and Calopterygidae species found in GenBank / DDJB. 


\section{Methods}

\section{DNA Extraction and Polymerase Chain Reaction Amplification, Sequence Alignment}

We used the sequence data of the mitochondrial COI gene (3P; $795 \mathrm{bp})$, COll gene (5P; $548 \mathrm{bp}), 16 \mathrm{~S}$ rRNA (517 bp), and the nuclear 28S rRNA gene (825 bp). See our newly obtained data with accession numbers shown in Table 1. See Osozawa et al. (2017c) for analytical details, including the primer set used.

Note that these $\mathrm{COI}$ and $\mathrm{COII}$ gene data are intersecting the nonprotein cording tRNA-Leu region (Osozawa et al., 2017c), and the corresponding region data are seldom found in the DDBJ / GenBank, but we included sequence data in our analyses from DDBJ / GenBank as noted above (no isolate and only species name in Fig. 2).

\section{Quaternary geologic event: Ryukyu continental islands formed at 1.55 Ma for BEAST v1.X analyses}

Osozawa et al. (2012) showed that the Ryukyu islands formed by back-arc spreading of the Okinawa trough that separated them from the Chinese mainland. This sea-floor spreading resulted in separation of the islands by $1.55 \pm 0.15 \mathrm{Ma}$ and this separation has increased progressively since then. Subsidence to form each island progressed rapidly, and these islands were simultaneously separated from the China mainland and isolated from one another by the development of the Okinawa trough, as well as other major seaways between the islands, including the Tsushima and Taiwan straits (Fig. 3). These straits, including minor ones in some cases, are expected to have acted as migration barriers to trigger vicariance, so $1.55 \mathrm{Ma}$ is a geologically robust calibration date applied to our phylogenetic analyses in BEAST v1.X for six Odonata groups of Stylogomphus (Gomphidae; calibration point Q1), Asiagomphus (Gomphidae; Q2; A. hainanensis in China was not collected; Sympatric A. pryeri and A. coreanus were not included in the Asiagomphus ingroup), Chlorogomphus (Chlorogomphoidea; Osozawa and Wakabayashi, 2015; Q3), Anotogaster (Cordulegastridae; Kiyoshi, 2008; Osozawa et al., 2013; Q4), Rhipidolestes (Megapodagrionidae; Q5; Chinese species was not collected), and Coeliccia (Platycnemididae; Osozawa et al., 2017c; Q6) in Fig. 2 (Locality map: Fig. 3).

\section{Geologic assessment of Odonata fossil dates for BEAST analyses}

Misof et al. (2014) constructed a whole insect timetree including three representative suborder species of Odonata (including E. superstes) by applying voluminous data of 1478 protein-coding genes, and estimated the basal node at $479 \mathrm{Ma}$ (= basal node age of Archaeognatha) by employing BEAST v.1.8. They stated that their calibration date strictly follows the protocol proposed by Parham et al. (2012), that is geologically robust in the opinion of the present authors. We agree with their statements that "Review the published geological age and the stratigraphic range of the fossil and synchronize the data with the most updated standard global geochronology". "Review the quality of the stratigraphic information for each fossil. In particular, amber deposits such as those from the Baltic or Dominican Republic could not be adequately correlated with the geological time scale". Therefore, they have largely excluded amber fossils from their analysis, with an exception of Burmese amber, which was dated at $99 \mathrm{Ma}$ using U-Pb 
method (Shi et al., 2012). "Biostratigraphic information has been updated and adapted to the current geological time scale" (the most recent International Chronostratigraphic Chart by the International Commission on Stratigraphy).

Misof et al. (2014) used the calibration date for fossil egg insertion scars into host plant by damselfly (Moisan et al., 2012) and considered the basal node of Odonata to be late Triassic (235-221 Ma). However, the Madygen Formation in Kyrgyzstan (Voigt et al. 2006) that yielded this fossil has associated no constraining radioisotopic age data and no reliable biostratigraphic information (no index fossils that can be related to robust absolute age determination), so we consider this late Triassic date to be poorly supported, and we used alternatively reliable early Jurassic date for damselfly (see below).

Kohli et al. (2016) examined many crown dates available for Odonata fossil calibration. Family level classification of Odonata is by wing venation patterns also as for fossil wings, as illustrated in Ozono et al. (2015). Kohli et al. (2016) reviewed such fossil data, and proposed the crown age for each family. However, there is some uncertainty of the fossil ages (NOT fossil identifications), so we reevaluated the geologic constraints associated with the fossil locations. We adopted several pre-Quaternary calibration dates, after evaluating their geological reliability, including, but not limited to, whether the fossil ages were constrained by modern and more accurate radioisotopic dating or by stratigraphical correlation. We applied 11 fossil calibration points from A to I (Figs. 1 and 2), and resulting in robust time calibration as old as $400 \mathrm{Ma}$. Note that the Devonian calibration point A was for Archaeognatha, and the Carboniferous calibration point B was for Ephemeroptera (our own biblographic survey and reevaluation; Figs. 1 and 2).

The labels preceding each text section below correspond to that given in the following section as calibration points on actual BEAST v1.X analysis (Figs. 1 and 2). These fossil dates are evaluated in order of decreasing age from $A$ to $I$. As will be seen in the subsequent section, the ages with larger uncertainties were not used in BEAST analyses for generating Figs. 1 and 2.

A: Gigamachilis triassicus gen. et sp. nov. (Archaeognatha) was collected from the Kalkschieferzone (239.51 $\pm 0.15 \mathrm{Ma}$; Stockar et al., 2012) of Monte San Giorgio (UNESCO World Heritage Site, SwitzerlandItaly) (Montagna et al., 2017). They noted that $G$. triassicus, possessing morphological features that prompt its assignment to the extant archaeognathan ingroup Machilidae, places the origin of modern lineages to Middle Triassic. However, the oldest fossil considered as Archaeognatha was from the Devonian (Emsian; 407.6 - 393.3 Ma; $400.45 \pm 7.15 \mathrm{Ma}$ ) from Gaspé, Québec (Labandeira et al., 1988), and we adopted this date for the calibration point A of Archaeognatha.

B: Knecht et al. (2011) reported an evidence of a full body impression of a flying insect from the Late Carboniferous Wamsutta Formation of Massachusetts, representing the oldest trace fossil of Pterygota, i.e., Ephemeroptera (mayfly). We considered the date the Gzhelian between 298.9 - 303.7 Ma (following Cohen et al., 2013; $301.3 \pm 2.4 \mathrm{Ma}$ ).

C: Wing pattern of fossil Liassophlebia resembles to that of Epiophlebia superstes included in the former Anisozygoptera (Nel et al., 1993), and the basal node represents crown Epiprocta (Anisozygoptera + 
Anisoptera) (Kohli et al., 2016). Liassophlebia fossil was found from the Bayreuth Formation between the Keuper (one of the three Triassic strata in Germany) and the Gryphaeensandstein Formation (Kohli et al., 2016). The stratigraphy is well established, and the correlated age of the Hettangian (Lowermost Jurassic) is 201.3- 199.3 Ma (200.3 $\pm 1.0 \mathrm{Ma})$.

D: Sinacymatophlebia mongolica, included in Anisoptera (Nel and Huang 2009), was from the Daohugou Biota, Inner Mongolia. The U-Pb age of the strata, that also constrains the age of feathered dinosaurs, was determined as $160.54 \pm 0.99 \mathrm{Ma}$ (Liu et al., 2012). U-Pb ages of ca.160 Ma from the Daohugou beds were also obtained by Liu et al. (2006).

E1: The Solnhofen limestone famous for Archaeopteryx yielded Prohemeroscopus jurassicus, of which wing pattern is similar to the present Chlorogomphoidea (Beckly et al., 1998). The biostratigraphic age using ammonite fossils is Tithonian (152.1-145.0 Ma; $148.5 \pm 3.6 \mathrm{Ma}$; Stuttgart 2007). E2: The Solnhofen limestone also yielded Zygoptera fossils (Beckly, 2019), and the calibration point E2 is at $148.5 \pm 3.6 \mathrm{Ma}$.

F: The upper Purbeck Limestone in England yielded insect fossils including Petalurida dragonfly, Anglopetalura magnifica ( $\mathrm{Nel}, 2009)$. The age is stratigraphically correlated to the Berriasian (the lowermost Cretaceous; $145-139.8 \mathrm{Ma} ; 142.4 \pm 2.6 \mathrm{Ma}$ ). Petaluridae fossils are also known from Argentina, and the Ar-Ar age for these strata is $119.65 \rrbracket \pm 0.45 \mathrm{Ma}$ (Petruleviciusa and Nel, 2003; but not adopted because the age is younger than the above fossil locality).

G: Liogomphus yixianensis (Gomphidae; G1), Rudiaeschna limnobia (Aeshnidae; G2), and Mesocordulia boreala (Corduliidae; G3) were described from the Jehol Biota, northern China (Ren and Guo, 1996). The Jehol Biota horizon was dated by the Ar-Ar method applied to intercalated silicic tuff, and the date is $130.7 \pm 1.4 \mathrm{Ma}$ (He et al., 2006).

The Santana Formaton at northeast Brazil (near the Atlantic margin) is famous for well-preserved fish fossils but also includes fossils of Cordulagomphus, Proterogomphidae dragonfly (Petrulevicius et al., 2012). Although no reliable index fossil are present and no volcanic rock is interbedded for radiometric dating, the age is considered to be coeval with the breakup of the supercontinent Gondwana and initiation of the Atlantic Ocean, and may be Aptian, Albian or possibly Cenomanian in Cretaceous, a rather loosely-constrained date (ca.125- 100 Ma; Martill, 2007); so this calibration point was not adopted.

The Burmese amber yielded Aeshnoptera (ancestral Aeshnidae; Huang et al., 2017) and other well preserved damselfly fossils (Euphaeidae, Coenagrionidae included in BEAST v1.X analyses; Fig. 2), and the U-Pb age is $98.79 \pm 0.62 \mathrm{Ma}$ (Shi et al., 2012; not adopted because of the younger age).

$\mathrm{H}$ : The Green River Formation, USA, yielded well preserved insect fossils including Libellulidae and Zygoptera (Grande, 1980). Ar-Ar dating applied to the silicic tuff within the formation yields ages of 53.5 48.5 Ma (weighted average age of $51.25 \pm 0.31 \mathrm{Ma}$; Smith et al., 2003). 
Libellulidae is also found from the famous fossil locality of Cereste, southern France (Nel and Paicheler, 1993), including Lethe butterfly (Nel et al., 1993; Pfretzschner, 1998) mentioned in Osozawa et al. (2017a). The assigned age is loosely constrained as middle Oligocene (33.9-23.03 Ma; Ducreux et al., 1985), which represents a large relative uncertainty, so this age is not adopted for calibration, also considering the younger age than the Green River Formation.

I: Wing fossils of Calopteryx japonica (=Matrona basilaris japonica; analyzed and shown in Fig. 2) and Oligoaeschna pryeri (no reliable COI-COll sequence data were obtained) were found from the fluvial to deltatic strata of the Beppu-Shimabara graben (Esaki and Asahina, 1957), northeastern extension and branch of the Okinawa trough (Fig. 1; cf., Osozawa K. et al., 2016). The fission track age of the dacitic tuff breccia within these strata is $1.76 \pm 0.22 \mathrm{Ma}$, and the strata are magnetically reversed and considered within the Matsuyama Chron (2.58- $0.77 \mathrm{Ma}$; Okaguchi and Otsuka, 1980) consistent with the above fission track age.

\section{Phylogenetic analyses by BEAST v1.X; Age calibration}

Bayesian inference $(\mathrm{BI})$ trees were constructed using the software BEAST v1.X. The BEAGLE Library must be downloaded beforehand to operate the platform software of BEAST. The details are described in Osozawa et al. (2017a-c) (see the "BEAST manual" at

http://kawaosombgi.livedoor.blog/ for a graphic explanation).

In BEAUti, "Taxa" and "Priors" (date setting is in "Prior"; date should be set in box of "tMRCA") were set as follows for ingroup species relative to four partitions of COI, COII, 16S rRNA, and 28S rRNA. These partitions automatically appear in "Partitions" if these sequence data are uploaded by using the plus button or by "Import Data". The protocol is that a MRCA at each calibration of point of A to I and Q1 to Q6 initiated to differentiate into the ingroup species.

Q1: Stylogomphus, Q2: Asiagomphus, Q3: Anotogaster, Q4: Chlorogomphus, Q5: Rhipidolestes, Q6: Coeliccia: $1.55 \pm 0.15(\mathrm{Ma})$ as tMRCA.
A: Archaeognatha: $400.45 \pm 7.15(\mathrm{Ma})$.
B: Ephemeroptera : $301.3 \pm 2.4(\mathrm{Ma})$.
C: Epiophlebia superstes (checked “Stem” box): $200.3 \pm 1.0$ (Ma).
D: Anisoptera excepting E. superstes: $160.5 \pm 1.0(\mathrm{Ma})$.
E1: Chlorogomphoidea: $148.5 \pm 3.6(\mathrm{Ma})$, E2: Zygoptera: $148.5 \pm 3.6(\mathrm{Ma})$.
F: Petaluridae: $148.5 \pm 3.6(\mathrm{Ma})$.
G1: Gomphidae, G2: Aeshnidae, G3: Corduliidae: $130.7 \pm 1.4$ (Ma). 
H: Libellulidae: $51.2 \pm 0.3(\mathrm{Ma})$.

I: Calopteryx + Matrona: $1.76 \pm 0.22(\mathrm{Ma})$.

In FigTree, posterior probability ("posterior"), posterior age ("Node ages"), and "rate median" (not constant because we applied relaxed clock model) can be output, and these are shown on each node in Fig. 3 . We made base substitution rate ("rate median" shown at each node in FigTree) vs age ("Node age" shown at each node in FigTree) diagram (Fig.3 left bottom inset).

\section{Declarations}

\section{Acknowledgements}

We thank Koji Tojo and Takuya Murata (Rhipidolestes), Kunihiko Matsuhira, Yoshinori Kubota, Hidetoshi Sugita, Fumiyasu Sato, Takehiko Yamanaka, Junko Kobayashi, Kyoji Osozawa, and Akira Mishima for making available analyzed samples. Bor-ming Jahn (Taiwan University; deceased 1 December, 2016), Ping-Shih Yang (Taiwan University), Chin-Ho Tsai (National Dong Hwa University), and Jen-Zon Ho and Hua-Te Fang (Endemic Species Research Institute) supported sample collections and obtained permission to collect in Taiwan. This project was partly financed through the Osozawa Fund (Former), Tohoku University. We thank Keiji Nunohara (Nunohara Office for Geological Survey), Kohei Sugawara (Ecofarm GSK), CTI Engineering Co., Ltd., and NEWJEC, Inc. for contributing to this fund.

\section{Author Contributions}

Soichi Osozawa (Japanese geologist) coordinated the research, carried out the BEAST analyses, and wrote this paper, and John Wakabayashi (native English-speaking American geologist) edited the writing.

\section{Additional Information}

Supplementary information accompanies this paper at

http://kawaosombgi.livedoor.blog/archives/11386037.html

\section{Competing Interests}

The authors declare no competing interests.

\section{Ethical approval}

Sequence data in Table 1 are available in GenBank / DDBJ.

\section{Data Availability}

The datasets analyzed during the current study are available from the corresponding author on reasonable request. 


\section{References}

1. Asahina S. A morphological study of a relic dragonfly Epiophlebia superstes Selys (Odonata, Anioszygoptera). The Japan Society for the Promotion of Science. 1954; 153 pp, Tokyo.

2. Bechly G. New fossil Odonata from the Upper Jurassic of Bavaria with a new fossil. Palaeoentomology. 2019; 002 (6): 618-632.

3. Bechly G, Nel A, Martinez-Delclos X, Fleck G. Four new dragonflies from the Upper Jurassic of Germany and the Lower Cretaceous of Mongolia (Anisoptera: Hemeroscopidae, Sonidae, and Proterogomphidae fam. nov.). Odonatologica. 1998; 27:149-187.

4. Benton MJ, Donoghue PCJ, Asher RJ, Friedman M, Near TJ, Vinther J. Constraints on the timescale of animal evolutionary history. Palaeontologia Electronica. 2015; 18.1.1FC: 1-106; palaeoelectronica.org/content/fc-1

5. Brower AVZ. Rapid morphological radiation and convergence among races of the butterfly Heliconius erato inferred from patterns of mitochondrial DNA evolution. Proceedings of the National Academy of Sciences of the United States of America. 1994; 91: 6491-6495.

6. Buatois LA, Mángano MG. The other biodiversity record: Innovations in animal-substrate interactions through geologic time. GSA Today. 2018; 28: https://doi.org/10.1130/GSATG371A.1.

7. Busse S, von Grumbkow P, Hummel S, Shah DN, Shah RDT, Li J, Zhang X, Yoshizawa K, Wedmann S, Hornschemeyer T. Phylogeographic analysis Elucidates the influence of the ice ages on the disjunct distribution of relict dragonflies in Asia. PloSOne. 2012; 7: e38132.

8. Cerling TE, Harris JM, MacFadden BJ, Leakey MG, Quade J, Eisenmann V, Ehleringer JR. Global vegetation change through the Miocene/Pliocene boundary. Nature. 1997; 389, 153- 158.

9. Cohen KM, Finney S, Gibbard PL. International Chronostratigraphic Chart. International Commission on Stratigraphy. 2013.

10. Coram RA, Nel A. A new petalurid dragonfly from the Lower Cretaceous of southern England (Odonata: Petalurida ?: Cretapetaluridae). Palaeodiversity2009. 2; 205-208.

11. Corbet PS. Dragonflies, Behavior and Ecology of Odonata. 1999; pp. 829. Harley Books, Colchester.

12. Drummond AJ, Suchard MA, Xie D, Rambaut A. Bayesian phylogenetics with BEAUti and the BEAST 1.7. Molecular Biology and Evolution. 2012; 29: 1969-1973.

13. Franks PJ, Royer DL, Beerling DJ, Van de Water PK, Cantrill DJ, Barbour MM, Berry JA. New constraints on atmospheric $\mathrm{CO} 2$ concentration for the Phanerozoic. Geophysical Research Letters. 2014; 31: 4685-4694. doi:10.1002/2014GL060457

14. Esaki T, Asahina S. On two Tertiary dragonfly species from the Oya-formation in Kazusa, Nagasaki Prefecture. Konchu (Journal of the Entomological Society of Japan). 1957; 25: 82-88.

15. Grande L. Paleontology of the Green River Formation with a review of the fish fauna. The Geological Survey of Wyoming Bulletin. 1980; 63: 1-333.

16. Gunther F, Li J, Schorr M, Nel A, Zhang X, Lin L, Gao M. Epiophlebia sinensis Li \& Nel 2011 in Li et al. (2012) (Odonata) newly recorded in North Korea. International Dragonfly Fund - Report. 2013; 61: 1- 
4.

17. Hara Y, Imanishi Y, Satta Y. Reconstructing the demographic history of the human lineage using whole-genome sequences from human and three great apes. Genome Biology and Evolution. 2012; 4: $1133-1145$.

18. Hasegawa E, Kasuya E. Phylogenetic analysis of the insect order Odonata using $28 \mathrm{~S}$ and $16 \mathrm{~S}$ rDNA sequences: a comparison between data sets with different evolutionary rates. Entomological Science. 2006; 9: 55-66.

19. He HY, Wang XL, Jin F, Zhou ZH, Wang F, Yang LK, Ding X, Boven A, Zhu RX. The 40Ar/39Ar dating of the early Jehol Biota from Fengning, Hebei Province, northern China. Geochemistry, Geophysics, Geosystems. 2006; 7: Q04001. doi:10.1029/2005GC001083 ISSN: 1525-2027

20. Ho S. The molecular clock and estimating species divergence. Nature Education. 2008; 1: 168.

21. Ho SY, Phillips MJ, Cooper A, Drummond AJ. 2005. Time dependency of molecular rate estimates and systematic overestimation of recent divergence times. Molecular Biology \& Evolution 22: 15611568.

22. Ho SY, Robert Lanfear R, Bromham L, Phillips MJ, Soubrier J, Rodrigo AG, Alan C. Time-dependent rates of molecular evolution. Molecular Ecology. 2011. doi: 10.1111/j.1365-294X.2011.05178.x

23. Huang D, Cai C, Nel A, Bechly G. A new dragonfly family from the mid Cretaceous Burmese amber (Odonata: Aeshnoptera: Burmaeshnidae). Cretaceous Research. 2017; 78: 8-12.

24. Ishida S, Ishida K, Kojima K, Sugimura M. Illustrated guide of identification of the Japanese Odonata. 1988; pp. 140. Tokai University Press. In Japanese.

25. Ishiwata K, Sasaki G, Ogawa G, Miyata T, Su ZH. Phylogenetic relationships among insect orders based on three nuclear protein-coding gene sequences. Molecular Phylogenetic Evolution. 2011; 58: 169-180.

26. Kiyoshi T. Differentiation of golden-ringed dragonfly Anotogaster sieboldii (Selys, 1854) (Cordulegastridae: Odonata) in the insular East Asia revealed by the mitochondrial gene genealogy with taxonomic implications. Journal of Zoological Systematics and Evolutionary Research. 2008; 46: 105-109.

27. Kiyoshi T, Sota T. Differentiation of the dragonfly genus Davidius (Odonata: Gomphidae) in Japan inferred from mitochondrial and nuclear gene genealogies. Zoological Science. 2006; 23: 1-8.

28. Knecht RJ, Engel MS, Benner JS. Late Carboniferous paleoichnology reveals the oldest full-body impression of a flying insect. PNAS. 2011; 108: 6515-6519.

29. Kohli M, Letsch H, Greve C, Bethoux O, Deregnaucourt I, Liu S, Zhou X, Donath A, Mayer C, Podsiadlowski L, Machida R, Niehuis O, Rust J, Wappler T, Yu X, Misof B, Ware J. How old are dragonflies and damselflies? Odonata (Insecta) transcriptomics resolve familial relationships. 2020; bioRxiv.

30. Kohli MK, Ware JL, Bechly G. How to date a dragonfly: Fossil calibrations for odonates. Palaeontologia Electronica. 2016; 19.1.1FC: 1-14. 
31. Labandeira, CC, Beall BS, Hueber FM. Early insect diversification: Evidence from a Lower Devonian bristletail from Québec. Science. 1988; 242: 913-916.

32. Letsch H, Gottsberger B, Ware JL. Not going with the flow: a comprehensive time-calibrated phylogeny of dragonflies (Anisoptera: Odonata: Insecta) provides evidence for the role of lentic habitats on diversification. Molecular Ecology. 2016; 25: 1340-1353.

33. Liu Y, Liu Y, Zhang H. LA-ICPMS zircon U-Pb dating in the Jurassic Daohugou Beds and correlative strata in Ningcheng of Inner Mongolia. Acta Geologica Sinica. 2006; 80: 133-142.

34. Liu YQ, Kuang HW, Jiang XJ, Peng N, Xu H, Sun HY. Timing of the earliest known feathered dinosaurs and transitional pterosaurs older than the Jehol Biota. Palaeogeography, Palaeoclimatology, Palaeoecology. 2012; 323: 1-12.

35. Martill DM. The age of the Cretaceous Santana Formation fossil Konservat Lagerstatte of north-east Brazil: a historical review and an appraisal of the biochronostratigraphic utility of its palaeobiota. Cretaceous Research. 2007; 28: 895-920.

36. Misof $\mathrm{J}$ et al. Phylogenomics resolves the timing and pattern of insect evolution. Science. 2014; 346: 763-767.

37. Moisan P, Labandeira CC, Matushkina NA, Wappler T, Voigt S, Kerp. Lycopsid-arthropod associations and odonatopteran oviposition on Triassic herbaceous Isoetites. Palaeogeography Palaeoclimatology Palaeoecology. 2012; 344-345: 6-15.

38. Montagna M, Haug JT, Strada L, Haug C, Felber M, Tintori A. Central nervous system and muscular bundles preserved in a 240 million year old giant bristletail (Archaeognatha: Machilidae). Scientific Reports. 2017; 7: 46016. doi: 10.1038/srep46016

39. Montañez IP, Poulsen CJ. The late Paleozoic ice age: An evolving paradigm. Annual Review of Earth and Planetary Sciences. 2013; 41: 629-656. doi:10.1146/annurev.earth.031208.100118

40. Neige P. Events of increased biodiversity, 1st Edition, Evolutionary radiations in the fossil record. 2015; pp. 152. ISTE Press - Elsevier.

41. Nel A, Paicheler J. Les libellulidae fossiles. Un inventaire critique (Odon., Anisoptera, Libellu- loidea). Entomologica Gallica. 1993; 4: 166-190.

42. Nel A, Nel J, Balme C. Un nouveau Lepidoptere Satyrinae fossile del'Oligocène du Sud-Est de la France (Insecta, Lepidoptera, Nymphalidae). Linneana Belgica. 1993; 14: 20-36.

43. Okaguchi $\mathrm{M}$, Otsuka $\mathrm{H}$. Fission track ages of zircon crystals from tuff layers in the Kuchinotsu Group and from andesite of the Tatsuishi Formation. The Quaternary Research. 1980; 19: 75-85.

44. Osozawa K, Ogino S, Osozawa S, Oba Y, Wakabayashi J. Carabid beetles (Carabus blaptoides) from Nii-jima and O-shima isles, Izu-Bonin oceanic islands: dispersion by Kuroshio current and the origin of the insular populations. Insect Systematics \& Evolution. 2016; 47: 1-16.

45. Osozawa S, Wakabayashi J. Killer typhoons began to impact the Japanese islands from ca.1.55 Ma, based on phylogeography of Chlorogomphus (gliding dragonfly). Journal of Earth Science and Climatic Change. 2015; S3:003. doi: 10.4172/2157-7617.S3-003 
46. Osozawa S, Shinjo R, Armig R, Watanabe Y, Horiguchi T, Wakabayashi J. Palaeogeographic reconstruction of the $1.55 \mathrm{Ma}$ synchronous isolation of the Ryukyu Islands, Japan, and Taiwan and inflow of the Kuroshio warm current. International Geology Review. 2012; 54: 1369-1388.

47. Osozawa S, Su ZH, Oba Y, Yagi T, Watanabe Y, Wakabayashi J. Vicariant speciation due to $1.55 \mathrm{Ma}$ isolation of the Ryukyu islands, Japan, based on geological and GenBank data. Entomological Science . 2013; 16: 267-277.

48. Osozawa S, Takáhashi M, Wakabayashi J. Ryukyu endemic Mycalesis butterflies, speciated vicariantly due to isolation of the islands since 1.55 Ma. Lepidoptera Science. 2015a; 66: 8-14.

49. Osozawa S, Oba Y, Kwon,HY, Wakabayashi J. Vicariance of Pyrocoelia (Lampyridae; firefly) in the Ryukyu islands, Japan. Biological Journal of the Linnean Society. 2015b; 116: 412-422.

50. Osozawa S, Fukuda H, Kwon HY, Wakabayashi J. Quaternary vicariance of tiger beetle, Cicindela chinensis, in Ryukyu, Japan, Taiwan and Korea-China. Entomological Research. 2016. 46; 122-127.

51. Osozawa S, Takáhashi M, Wakabayashi J. Quaternary vicariance of Ypthima butterflies (Lepidoptera, Nymphalidae, Satyrinae) and systematics in the Ryukyu Islands and Oriental region. Zoological Journal of the Linnean Society. 2017a; 180: 593-602. doi: https://doi.org/10.1093/zoolinnean/zlw009

52. Osozawa S, Shiyake S, Fukuda H, Wakabayashi J. Quaternary vicariance of Platypleura (Cicadidae) in Japan, Ryukyu, and Taiwan islands. Biological Journal of the Linnean Society. 2017b; 121: 185199. doi: https://doi.org/10.1093/biolinnean/blw023

53. Osozawa S, Sato F, Wakabayashi J. Quaternary vicariance of lotic Coeliccia in the Ryukyu-Taiwan islands contrasted with lentic Copera. Journal of Heredity. 2017c; 108: 280-287. doi: https://doi.org/10.1093/jhered/esx007

54. Ozono A, Kawashima I, Futahashi R. Dragonflies of Japan. 2012; pp. 531. Bun-ichi Co. Ltd.

55. Papadopoulo A, Anastasiou I, Vogler AP. Revisiting the insect mitochondrial molecular clock: The mid-Aegean trench calibration. Molecular Biology and Evolution. 2010; 27: 1659-1672.

56. Parham JF, Donoghue PC, Bell CJ, Calway TD, Head JJ, HolroydPA, Inoue JG, Irmis RB, Joyce WG, Ksepka DT, Patané JS, Smith ND, Tarver JE, van Tuinen M, Yang Z, Angielczyk KD, Greenwood JM, Hipsley CA, Jacobs L, Makovicky PJ, Müller J, Smith KT, Theodor JM, Warnock RC, Benton MJ. Best practices for justifying fossil calibrations. Systematic Biology. 2012; 61:346-359.

57. Petruleviciusa JF, Nel A. Oldest Petalurid dragonfly (Insecta: Odonata): a Lower Cretaceous specimen from south Patagonia, Argentina. Cretaceous Research. 2003; 24: 31-34.

58. Petruleviciusa JF, Martins-Neto RG, Azar D, Makhoul E, Nel A. Full description of Cordulagomphus primaerensis from Santana Formation (Lower Cretaceous of Brazil) (Odonata: Aeshnoptera: Proterogomphidae). Zootaxa. 2012; 3503: 55-60.

59. Pfretzschner HU. Ein weiteres exemplar von Lethe? Corbieri Nel 1993 (Lepidoptera, Satyridae) aus dem Unter- Oligozan von Cereste (Sud-Frankreich). Palaontologische Zeitschrift. 1998; 72: 56-64.

60. Ren, D, Guo Z. Three new genera and three new species of dragonflies from the late Jurassic of northeast China (Anisoptera: Aeshnidae, Gomphidae, Corduliidae). Entomologia Sinica. 1996; 3: 95- 
105.

61. Rohde RA, Muller RA. 2005. Cycles in fossil diversity. Nature 434, 208-210.

62. Sahney S, Benton MJ, Ferry PA. Links between global taxonomic diversity, ecological diversity and the expansion of vertebrates on land. Biology Letters. 2010. doi:10.1098/rsbl.2009.1024

63. Shi G, Grimaldi DA, Harlow GE, Wang J, Wang J, Yang M, Lei W, Li Q, Li X. Age constraint on Burmese amber based on U-Pb dating of zircons. Cretaceous Research. 2012; 37: 155-163.

64. Smith ME, Singer B, Carroll A. 40 Ar/39 Ar geochronology of the Eocene Green River Formation, Wyoming. Geological Society of America Bulletin. 2003; 115: 549-565.

65. Stockar, R, Baumgartner, P O, Condon, D. Integrated Ladinian bio-chronostratigraphy and geochrononology of Monte San Giorgio (Southern Alps, Switzerland). Swiss Journal of Geosciences. 2012; 60: 239-269.

66. Stuttgart GS. Ammonite biostratigraphy as a tool for dating Upper Jurassic lithographic limestones from South Germany - first results and open questions. Neues Jahrbuch für Geologie und Paläontologie- Abhandlungen. 2007; 245: 117-125.

67. Suchard MA, Lemey P, Baele G, Ayres DL, Drummond AJ, Rambaut A. Bayesian phylogenetic and phylodynamic data integration using BEAST 1.10. Virus Evolution. 2018; 4: vey016.

DOI:10.1093/ve/vey016

68. Taira A. Search the Earth History, Geology 3. 2007; pp. 396. Iwanami Shoten, Publishers, Tokyo. (in Japanese)

69. Voigt S, Haubold H, Meng S, Krause D, Buchantschenko J, Ruckwied K. Götz AE. Die FossilLagerstätte Madygen: ein Beitrag zur Geologie und Paläontologie der Madygen-Formation (Mittel-bis Ober-Trias, SW-Kyrgyzstan, Zentralasien). Hallesches Jahrbuch für Geowissenschaften. 2006; 22: 85-119.

70. Ware JL, Beatty CD, Herrera MS, Valley S, Johnson J, Kerst C, May ML, Theischinger G. The petaltail dragonflies (Odonata: Petaluridae): Mesozoic habitat specialists that survive to the modern day. Journal of Biogeography. 2014; 41: 1291-1300.

71. Ware JL, Pilgrim E, May ML, Thomas W. Donnelly TW, Tennessen K. Phylogenetic relationships of North American Gomphidae and their close relatives. Systematic Entomology. 2017; 42: 347-358.

72. Xin Yu X, Bu W. A preliminary phylogenetic study Megapodagrionidae with focus on the Chinese genera Sinocnemis Wilson \& Zhou and Priscagrion Zhou \& Wilson (Odonata: Zygptera). Hydrobiologia. 2011; 665:195-203. doi 10.1007/s10750-011-0622-7

73. Zhai T, Yang HQ, Zhang, RC Fang LM, ZhongGH, Fang SG. Effects of population bottleneck and balancing selection on the Chinese Alligator are revealed by locus-specific characterization of $\mathrm{MHC}$ genes. Scientific Reports. 2017; 7: 5549. DOI:10.1038/s41598-017-05640-2

\section{Tables}

Due to technical limitations, table 1 is only available as a download in the Supplemental Files section. 


\section{Figures}

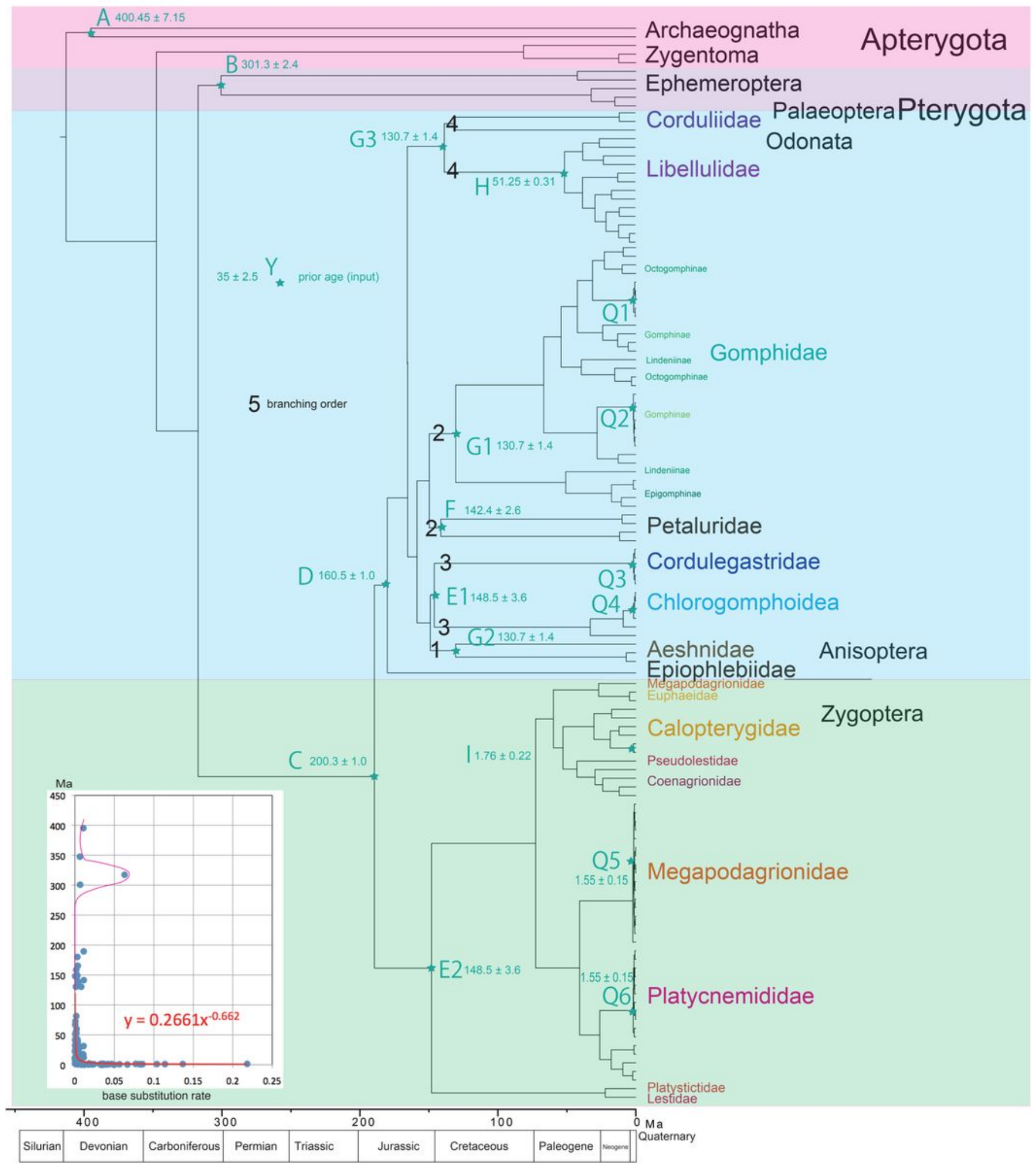

\section{Figure 1}

Simplified BI tree for combined genes of Odanata species, calibrated by both the $1.55 \mathrm{Ma}$ event and older fossil dates, using BEAST v1.X. Calibration point $\mathrm{H}$, for example, represents a crown node of a common ancestor of Libellulidae ingroup species, but the stem node can be specified if it is needed. In BEAUti, 
monophyletic can be specified for Libellulidae ingroup species. Note that the ingroup of calibration point Q6, for example, contains Chinese Platycnemididae species as well as Ryukyu-Taiwan species. Inserted Figure: Base substitution rate vs age diagram. Red thick curve with equation: Exponential trendline drawn by Excel function, Red thin curve: Free handed trendline drawn by connecting plots with maximum rate through the time around $320 \mathrm{Ma}$. Note: The designations employed and the presentation of the material on this map do not imply the expression of any opinion whatsoever on the part of Research Square concerning the legal status of any country, territory, city or area or of its authorities, or concerning the delimitation of its frontiers or boundaries. This map has been provided by the authors.

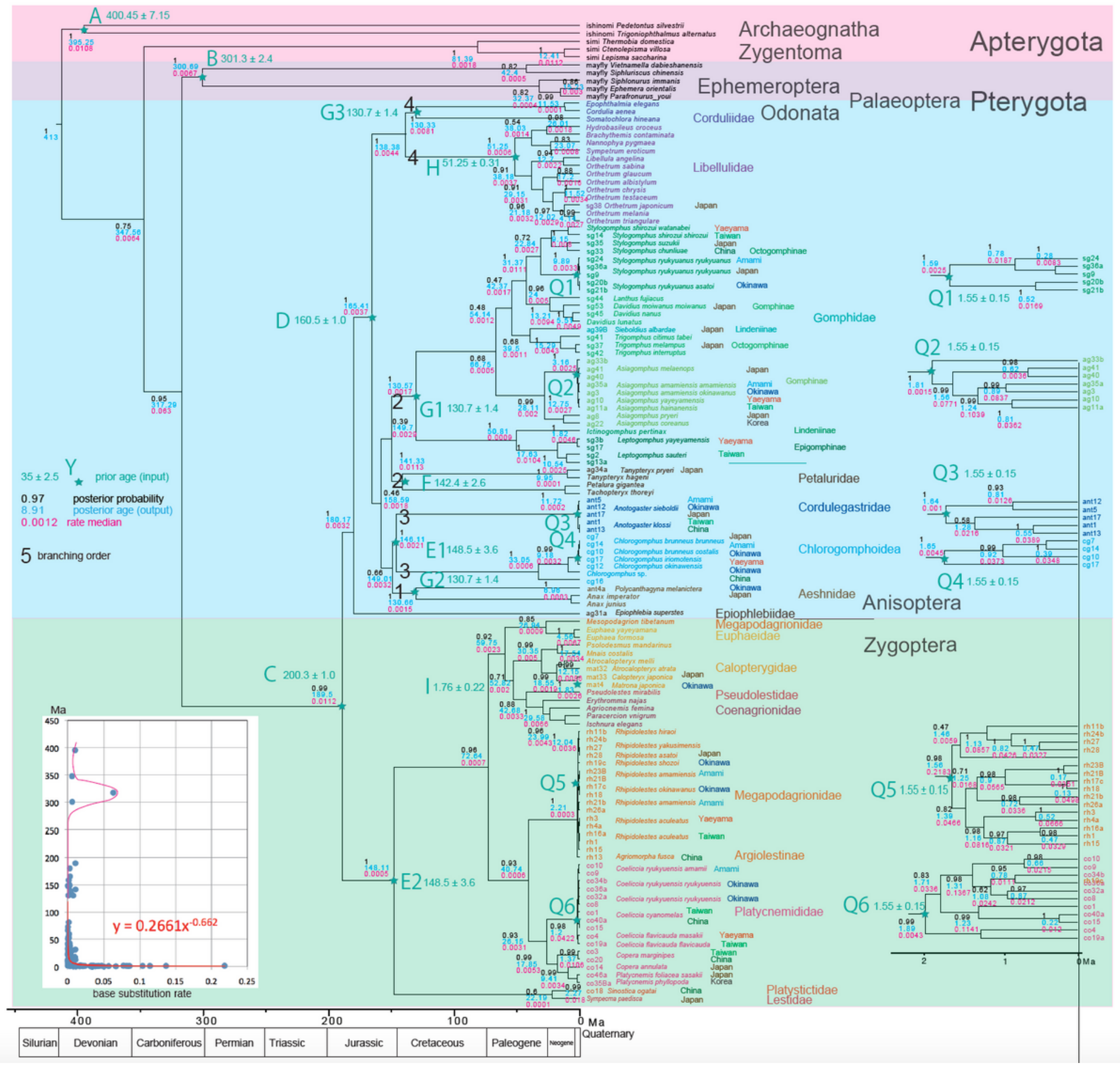

Figure 2 
$\mathrm{BI}$ tree for combined genes of Odanata species, calibrated by both the $1.55 \mathrm{Ma}$ event and older fossil dates, using BEAST v1.X. Inserted Figure: Base substitution rate vs age diagram. Red thick curve with equation: Exponential trendline drawn by Excel function, Red thin curve: Free handed trendline drawn by connecting plots with maximum rate through the time around $320 \mathrm{Ma}$.

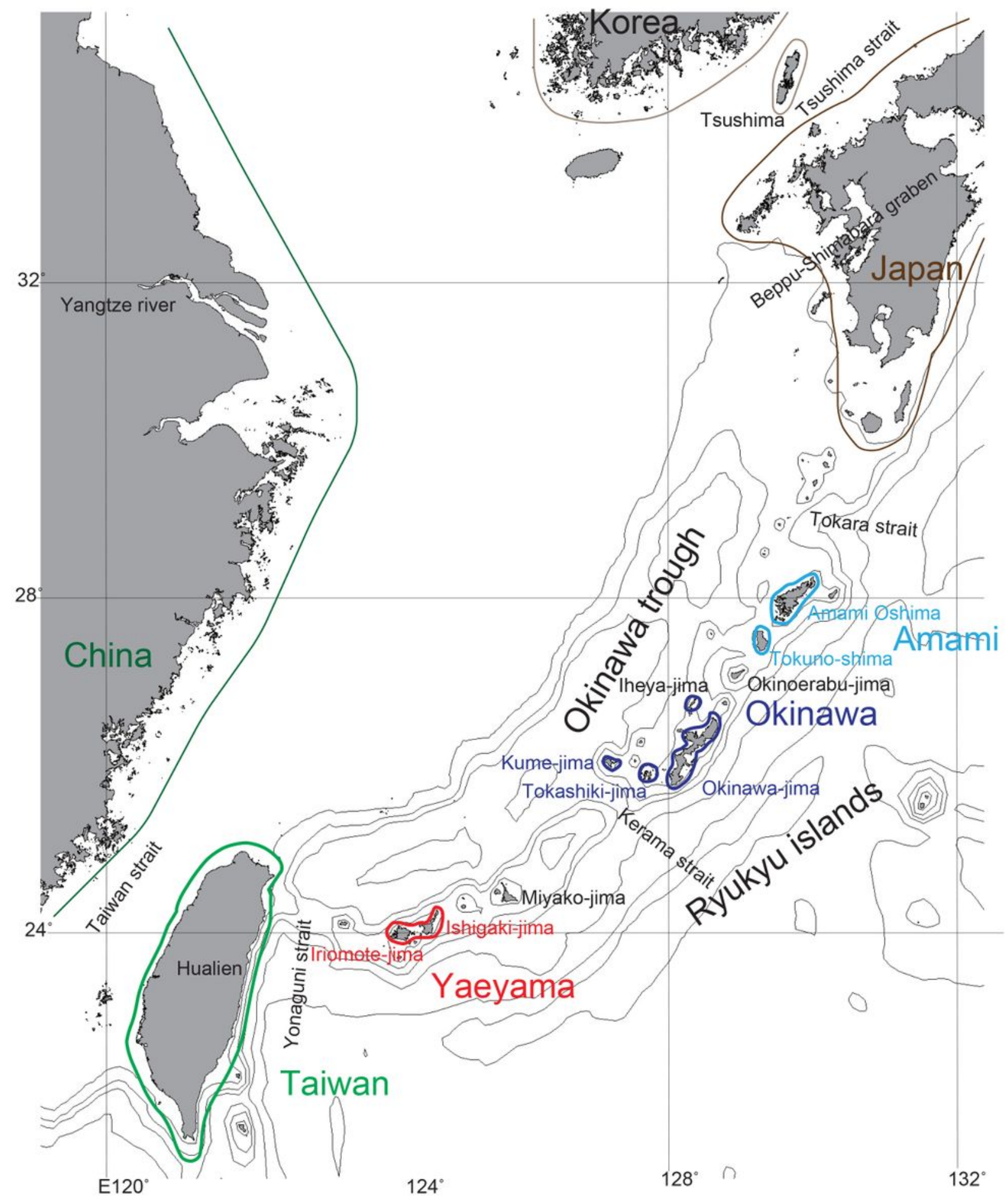

Figure 3 
Geographical map of the Ryukyu and Japan Islands, Taiwan, Korea, and China. Note: The designations employed and the presentation of the material on this map do not imply the expression of any opinion whatsoever on the part of Research Square concerning the legal status of any country, territory, city or area or of its authorities, or concerning the delimitation of its frontiers or boundaries. This map has been provided by the authors.
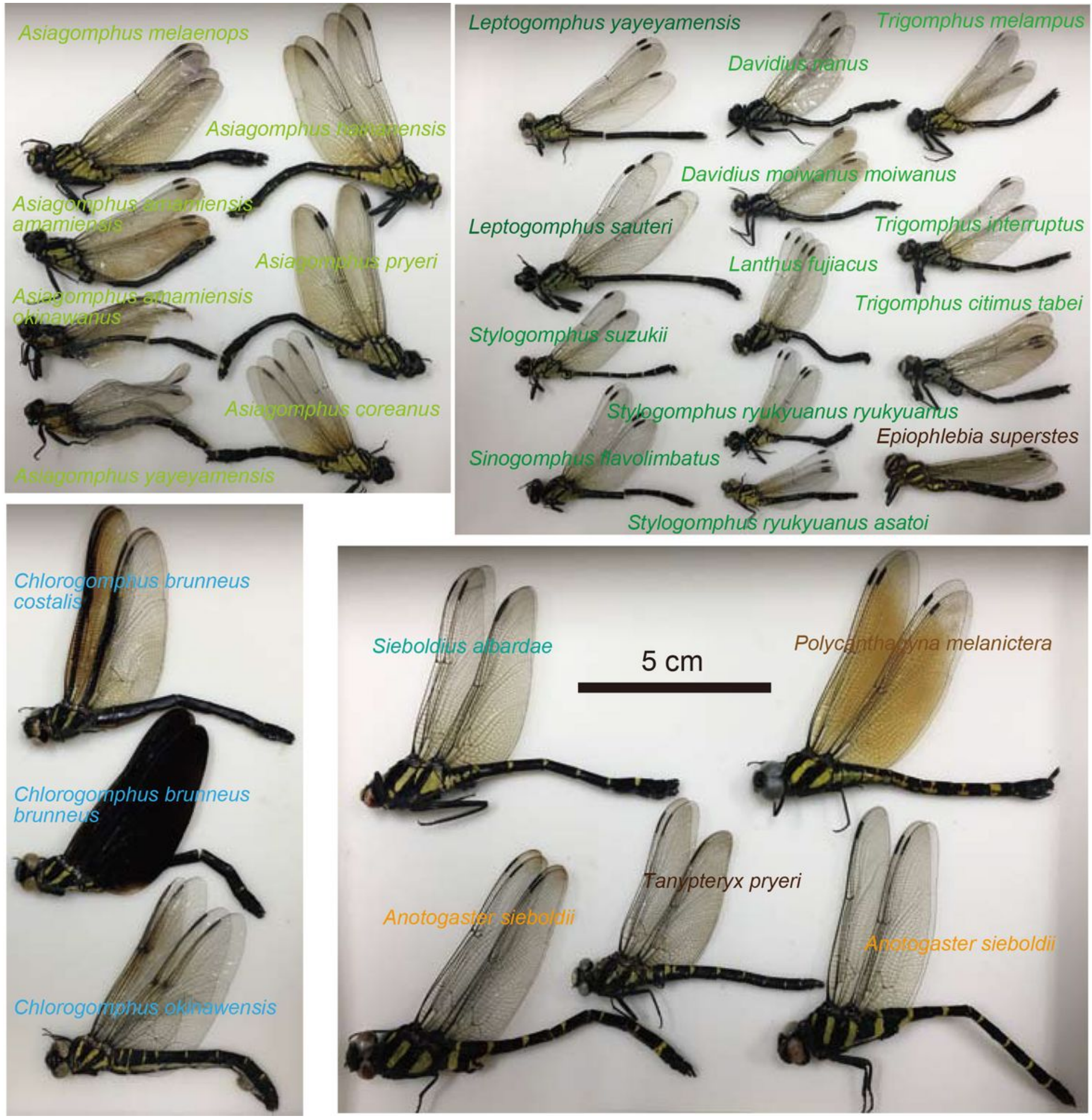

\section{Figure 4}

Anisoptera species analyzed in this paper. 


\section{Supplementary Files}

This is a list of supplementary files associated with this preprint. Click to download.

- Table1.pdf 